\title{
Crop Response to Soil Acidity Factors in Ultisols and Oxisols in Puerto Rico. VII. Dry Beans ${ }^{1,2}$
}

\author{
Fernando Abruña, José A. Rodríguez García and José Badillo Feliciano ${ }^{3}$
}

\begin{abstract}
Yields of dry beans on a Corozal clay (Ultisol) dropped sharply when acidity increased beyond $\mathrm{pH} 4.7$ and with $30 \% \mathrm{Al}$ saturation of the effective CEC of the soil. No crop was produced at $\mathrm{pH} 4.1$ with $80 \%$ Al saturation. Similar results were obtained on a Corozal clay subsoil, but the effect of increasing acidity on bean yields was much more marked. Lower yields were obtained on a Coto clay (Oxisol) with a relatively small response to soil acidity. For all soils combined, $\mathrm{pH}$ and percent Al saturation of the exchange capacity of the soil correlated very closely with yields. There was also a positive correlation between $\mathrm{Ca}$ content of the leaves and yields. Highest yields were obtained around pH 5.2 when there was essentially no exchangeable Al in the soil. Yields decreased to about $50 \%$ of maximum when $\mathrm{Al}$ saturation increased to $50 \%$, and no yields were produced when Al saturation of the soil approached $80 \%$.
\end{abstract}

\section{INTRODUCTION}

Dry beans (Phaseolus vulgaris L.) are a major source of protein in much of the tropics and large quantities are imported from temperate regions. Latin America produces about 35\% of world production (8). Nearly all the dry beans consumed in Puerto Rico, about 22,000 t annually, worth over $\$ 10$ million, are imported.

During the last decade $(4,5,7,10,12,14)$ abundant information on liming of soils planted to field beans has been published, but yield responses were rarely related to soil acidity factors.

The study reported here determined the effect of soil acidity factors on yields and foliar composition of dry bean growing on a Ultisol and an Oxisol.

\section{MATERIALS AND METHODS}

Field experiments were conducted on a Corozal soil and subsoil (Aquic Tropudults) at the Corozal Substation and on a Coto sandy clay (Tropeptic Haplorthox) at the Isabela Substation. There were thirty $4 \times 4-\mathrm{m}$ plots at each of the Corozal sites and 40 on the Coto soil. All plots were surrounded by ditches to prevent runoff from one plot to another, and

\footnotetext{
${ }^{1}$ Manuscript submitted to Editorial Board September 2, 1982.

${ }^{2}$ This paper covers work carried out cooperatively between Agricultural Research Service, USDA and the Agricultural Experiment Station, College of Agricultural Sciences, Mayagüez Campus, University of Puerto Rico.

${ }^{3}$ Soil Scientist, ARS, USDA; Assistant Agronomist and Agronomist, Agricultural Experiment Station, College of Agricultural Sciences, Mayagüez Campus, University of Puerto Rico, respectively.
} 
were arranged in complete randomized blocks. The plots had a wide range of soil acidity resulting from variable lime rates applied during previous years.

The soil in all plots was sampled before planting by 10 borings from 0 - to $15-\mathrm{cm}$ depths in each plot. The samples were air dried and passed through a 20-mesh screen. Exchangeable bases were extracted with $N$ $\mathrm{NH}_{4} \mathrm{OAc}$; $\mathrm{Ca}$ and $\mathrm{Mg}$ were determined by the Versenate method (9); and $\mathrm{K}$ by flame photometry. Exchangeable $\mathrm{Al}$ was extracted with $\mathrm{N} \mathrm{KCl}$ and

TABLE 1.-The effect of soil acidity factors on yields and foliar composition of the Bonita variety of white beans in Puerto Rico

\begin{tabular}{|c|c|c|c|c|c|c|c|c|}
\hline \multicolumn{2}{|c|}{ Soil acidity factors } & \multirow{2}{*}{ Yield } & \multicolumn{6}{|c|}{ Foliar composition } \\
\hline $\mathrm{pH}$ & $\begin{array}{c}\mathrm{Al} \\
\text { saturation }\end{array}$ & & $\mathrm{N}$ & $\mathrm{P}$ & $\mathrm{K}$ & $\mathrm{Ca}$ & $\mathrm{Mg}$ & $\mathrm{Mn}$ \\
\hline & $\%$ & $\mathrm{~kg} / \mathrm{ha}$ & & & $\%$ & & & $p / n$ \\
\hline \multicolumn{9}{|c|}{ Corozal clay } \\
\hline 6.0 & 0 & 1,810 & 4.87 & .27 & 1.84 & 1.13 & .39 & 228 \\
\hline 5.1 & 12 & 1,720 & 5.29 & .23 & 1.93 & 1.09 & .35 & 207 \\
\hline 4.9 & 24 & 1,680 & 5.45 & .23 & 1.90 & 1.08 & .31 & 320 \\
\hline 4.7 & 33 & 1,550 & 5.14 & .25 & 1.83 & 1.08 & .39 & 240 \\
\hline 4.4 & 51 & 1,030 & 5.31 & .26 & 1.87 & 1.08 & .40 & 306 \\
\hline 4.3 & 67 & 400 & 5.23 & .27 & 1.86 & .81 & .42 & 270 \\
\hline 4.1 & 80 & 0 & 4.19 & .27 & 1.96 & .77 & .35 & 340 \\
\hline \multicolumn{9}{|c|}{ Corozal clay-subsoil } \\
\hline 5.6 & 0 & 1,880 & 5.07 & .23 & 2.06 & 1.22 & .50 & 130 \\
\hline 5.0 & 12 & 1,370 & 5.24 & .25 & 2.11 & 1.14 & .49 & 140 \\
\hline 4.7 & 29 & 1,200 & 5.20 & .26 & 1.91 & .89 & .43 & 140 \\
\hline 4.6 & 39 & 1,120 & 5.09 & .25 & 1.91 & .98 & .52 & 175 \\
\hline 4.5 & 52 & 660 & 5.16 & .27 & 1.91 & .99 & .50 & 214 \\
\hline 4.2 & 66 & 150 & 5.54 & .30 & 1.63 & .78 & .50 & 202 \\
\hline 3.9 & 80 & 0 & 5.52 & .29 & 1.57 & .71 & .34 & 248 \\
\hline \multicolumn{9}{|c|}{ Coto sandy clay } \\
\hline 5.7 & 0 & 1,450 & 4.69 & .16 & 3.43 & 1.87 & .49 & 333 \\
\hline 5.0 & 7 & 1,390 & 4.65 & .15 & 3.65 & 1.68 & .42 & 388 \\
\hline 4.7 & 18 & 1,380 & 4.71 & .15 & 3.79 & 1.64 & .39 & 414 \\
\hline 4.5 & 32 & 1,260 & 4.75 & .14 & 3.38 & 1.59 & .39 & 616 \\
\hline
\end{tabular}

determined by the double titration method (11). The Al saturation percentage of the effective $\mathrm{CEC}$ was calculated by dividing the exchangeable $\mathrm{Al}$ by the sum of exchangeable $\mathrm{Ca}, \mathrm{Mg}, \mathrm{K}, \mathrm{H}$, and $\mathrm{Al}$. Soil reaction was measured with a glass electrode with a soil to water ratio of 1 to 1.5.

All plots were planted to the bean variety Bonita February 1978. Rows were $45 \mathrm{~cm}$ apart with plants $5 \mathrm{~cm}$ apart within the rows. All plots received $1000 \mathrm{~kg} / \mathrm{ha}$ of $10-10-10$ fertilizer containing $25 \mathrm{~kg} / \mathrm{t}$ of a minor 
TABLE 2.-Correlations between yield and plant factors of Bonita white beans and acidity factors of two Ultisols and an Oxisol

\begin{tabular}{|c|c|c|c|}
\hline \multirow{2}{*}{ Yield and plant factor } & \multicolumn{2}{|c|}{ Soil acidity components } & \multirow{2}{*}{$\begin{array}{l}\text { Exchangeable Al/ } \\
\text { Exchangeable bases }\end{array}$} \\
\hline & $\mathrm{pH}$ & Percent Al saturation & \\
\hline \multicolumn{4}{|c|}{ Corozal clay soil } \\
\hline & $r=.83^{* *}$ & $r=.91^{* *}$ & $r=.91^{* *}$ \\
\hline Grain yields & $\begin{array}{l}Y=19755.9+7453.8 X- \\
633.3 X^{2}\end{array}$ & $\mathrm{Y}=1839.2-1.09 \mathrm{X}-.29 \mathrm{X}^{2}$ & $Y=1928.3-980.2 X+117.9 X^{2}$ \\
\hline \multirow{3}{*}{$\%$ Ca content of leaves } & $\begin{aligned} r & =.70^{* *}\end{aligned}$ & $r=.76^{* *}$ & $r=.76^{* *}$ \\
\hline & $Y=3.77+1.71 X-.147 X^{2}$ & $\begin{array}{l}Y=1.1+.0025 X-.00009 \\
X^{2}\end{array}$ & $\mathrm{Y}=1.14-.17 \mathrm{X}+.015 \mathrm{X}^{2}$ \\
\hline & $r=.44^{*}$ & & \\
\hline Mn content of leaves (ppm) & $\begin{aligned} \mathrm{Y}=528.7 & -53.2 \mathrm{X} \\
r & =.71^{* *}\end{aligned}$ & Nonsignificant & Nonsignificant \\
\hline \multirow[t]{2}{*}{$\mathrm{Ca} / \mathrm{Mn}$ ratio of leaves } & $\mathrm{Y}=-66.78+25.29 \mathrm{X}$ & Nonsignificant & Nonsignificant \\
\hline & \multicolumn{2}{|c|}{ Corozal clay subsoil } & \\
\hline Grain yields & $\begin{array}{c}r=.87^{* *} \\
\mathrm{Y}=9795.7+3319.3 \mathrm{X}- \\
216.8 \mathrm{X}^{2}\end{array}$ & $\begin{array}{c}r=.81^{* *} \\
\mathrm{Y}=1758.3-21.8 \mathrm{X}\end{array}$ & $\begin{array}{c}r=.82^{* *} \\
\mathrm{Y}=1633.8-997.2 \mathrm{X}+141.9 \mathrm{X}^{2}\end{array}$ \\
\hline & $r=.82^{* *}$ & $r=.76^{* *}$ & $r=.82^{* *}$ \\
\hline$\%$ Ca content of leaves & $\begin{aligned} \mathrm{Y}=.99-.42 \mathrm{X} \\
r=.72^{* *}\end{aligned}$ & $\begin{array}{r}\mathrm{Y}=1.28-.007 \mathrm{X} \\
r=.73^{* *}\end{array}$ & $\begin{array}{c}\mathrm{Y}=1.22-.3 \mathrm{X}+.038 \mathrm{X}^{2} \\
r=.75^{* *}\end{array}$ \\
\hline Mn content of leaves (ppm) & $\begin{aligned} \mathrm{Y}=462.7 & -61.3 \mathrm{X} \\
r & =.86^{* *}\end{aligned}$ & $\begin{array}{r}\mathrm{Y}=128.2+1.2 \mathrm{X} \\
r=.73^{* *}\end{array}$ & $\begin{array}{c}\mathrm{Y}=131.56+70.57 \mathrm{X}-12.21 \mathrm{X}^{2} \\
r=.72^{* *}\end{array}$ \\
\hline \multirow[t]{2}{*}{$\mathrm{Ca} / \mathrm{Mn}$ ratio of leaves } & $\mathrm{Y}=22.7+66.2 \mathrm{X}$ & $\begin{array}{l}\mathrm{Y}=106.4-.83 \mathrm{X} \\
y \text { clay }\end{array}$ & $\mathrm{Y}=11.3-22.6 \mathrm{X}$ \\
\hline & $r=.48^{* *}$ & $r=.45^{* *}$ & $r=.45^{* *}$ \\
\hline Grain yields & $\begin{array}{l}Y=3243.7+1645.8 X=43.8 \\
X^{2}\end{array}$ & $Y=1415.7+8.2 X-.69 X^{2}$ & $\mathrm{Y}=1418.6+316.4 \mathrm{X}-3046 \mathrm{X}^{2}$ \\
\hline$\% \mathrm{Ca}$ content of leaves & $\begin{array}{l}\text { Nonsignificant } \\
\qquad r=.63^{* *}\end{array}$ & $\begin{array}{l}\text { Nonsignificant } \\
\qquad r=.51^{* * *}\end{array}$ & $\begin{array}{l}\text { Nonsignificant } \\
\qquad r=.51^{* *}\end{array}$ \\
\hline Mn content of leaves (ppm) & $\begin{array}{c}\mathrm{Y}=1260.8-165.6 \mathrm{X} \\
r=.66^{* *}\end{array}$ & $\begin{array}{r}\mathrm{Y}=351.2+8.34 \mathrm{X} \\
r=.48^{* * *}\end{array}$ & $\begin{array}{c}\mathrm{Y}=349.4+6-7.5 \mathrm{X} \\
r=.51^{* *}\end{array}$ \\
\hline $\mathrm{Ca} / \mathrm{Mn}$ ratio of leaves & $\mathrm{Y}=-165.8+45.1 \mathrm{X}$ & $\mathrm{Y}=71.4-76.2 \mathrm{X}$ & $\mathrm{Y}=74.3-76.0 \mathrm{X}$ \\
\hline
\end{tabular}


element mixture containing $\mathrm{Zn}, \mathrm{B}, \mathrm{Mo}, \mathrm{Cu}$ and $\mathrm{Fe}, 2$ weeks after planting. Plots were sprayed twice during the course of the experiment for control of insects and diseases and were hand weeded as required. Irrigation was applied when weekly rainfall was less than $20 \mathrm{~mm}$.

Before plants bloomed, leaves from the third pair were taken from plants in the central row of each plot, washed with distilled water, dried

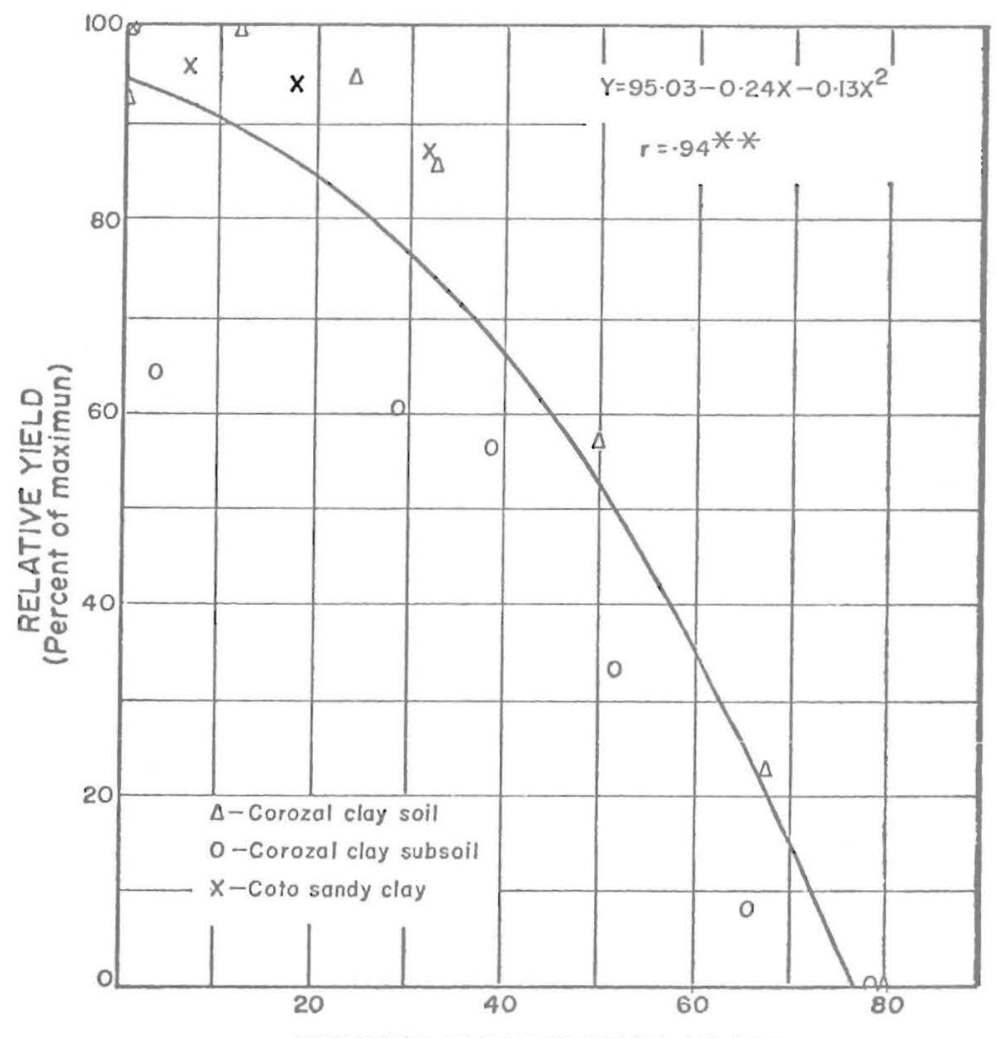

PERCENT AI SATURATION OF SOIL

FIG. 1.- Influence of percent aluminum saturation of three soils on relative yields of Bonita dry beans in Puerto Rico.

at $70^{\circ} \mathrm{C}$, ground and analyzed for $\mathrm{N}$ by the Kjeldahl method; for $\mathrm{P}$, colorimetrically; $\mathrm{Ca}$ and $\mathrm{Mg}$ by the Versenate method; and for $\mathrm{Mn}$, colorimetrically as permanganate after oxidation with $\mathrm{KIO}_{4}$.

All plots were harvested in May and the beans were dried to 14\% moisture content. The relationships between yield and soil acidity components were determined by regression analysis. 


\section{RESULTS AND DISCUSSION}

COROZAL CLAY SOIL

Yields were not affected by increasing soil acidity until $\mathrm{pH}$ dropped below 4.7 and $\mathrm{Al}$ saturation of the effective CEC of the soil increased beyond about $30 \%$ (table 1). As acidity increased beyond this level, bean yield dropped sharply. No crop was produced when $\mathrm{pH}$ reached 4.1 and Al saturation of the soil was $80 \%$ (table 1 ). Snap beans grown on this site have shown similar response to these soil acidity factors $(1,2)$.

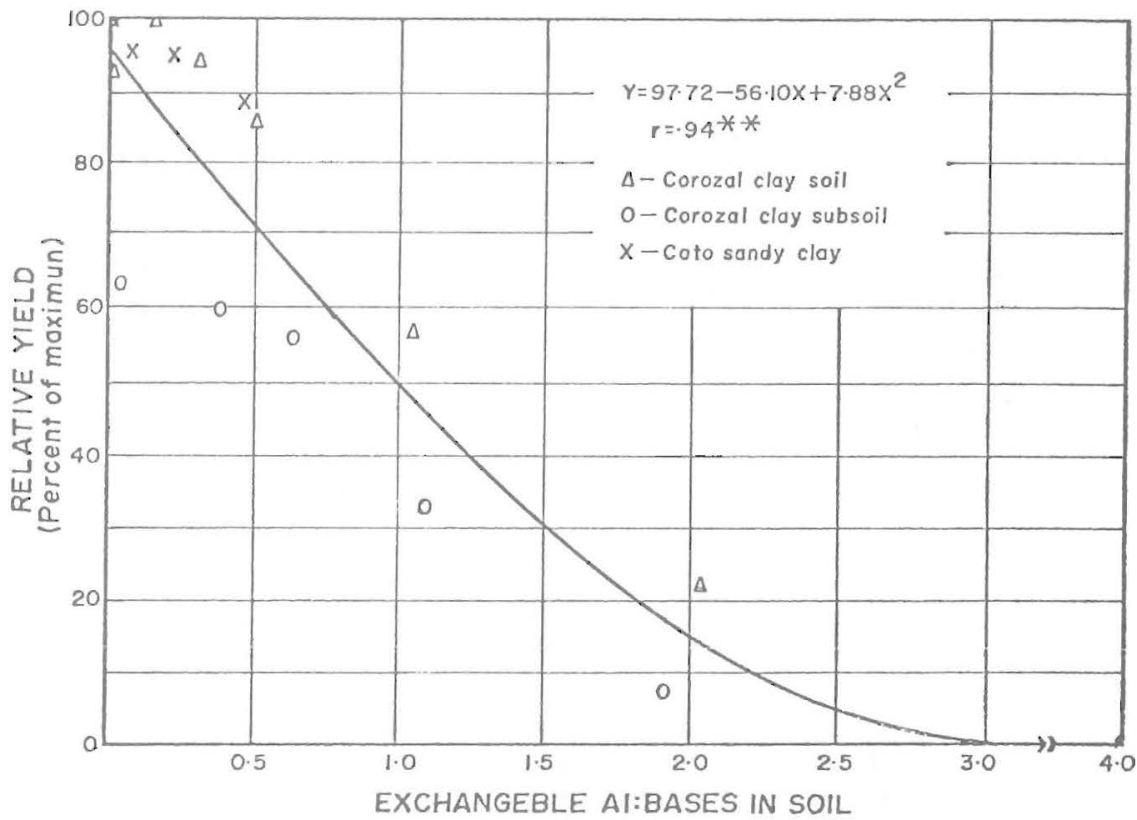

FIG. 2.-Relationship between exchangeable Al:bases and relative yields of Bonita dry beans on three soils in Puerto Rico.

Calcium content of the bean leaves was reduced when $\mathrm{Al}$ saturation of the soil dropped below $50 \%$ (table 1), but $\mathrm{Mn}, \mathrm{N}, \mathrm{P}, \mathrm{K}$ and $\mathrm{Mg}$ contents were not appreciably affected by soil acidity.

Yields were highly correlated with soil $\mathrm{pH}, \mathrm{Al}$ saturation, and exchangeable $\mathrm{Al} /$ exchangeable bases; and $\mathrm{Ca}$ content of the leaves correlated with these three soil acidity factors (table 2).

\section{COROZAL CLAY SUBSOIL}

Yields similar to those in the Corozal soil were produced on the Corozal subsoil when there was no exchangeable $\mathrm{Al}$ in the soil. However, the response of dry beans to increasing soil acidity was more marked in the 
subsoil than in the normal soil (table 1), possibly as a result of less organic matter in the subsoil (2.02\% and $4.11 \%$, respectively). Organic matter tends to reduce the effect of high Al contents on plant growth (6, 13).

Calcium content of the bean leaves decreased and Mn content increased with increasing soil acidity (table 1).

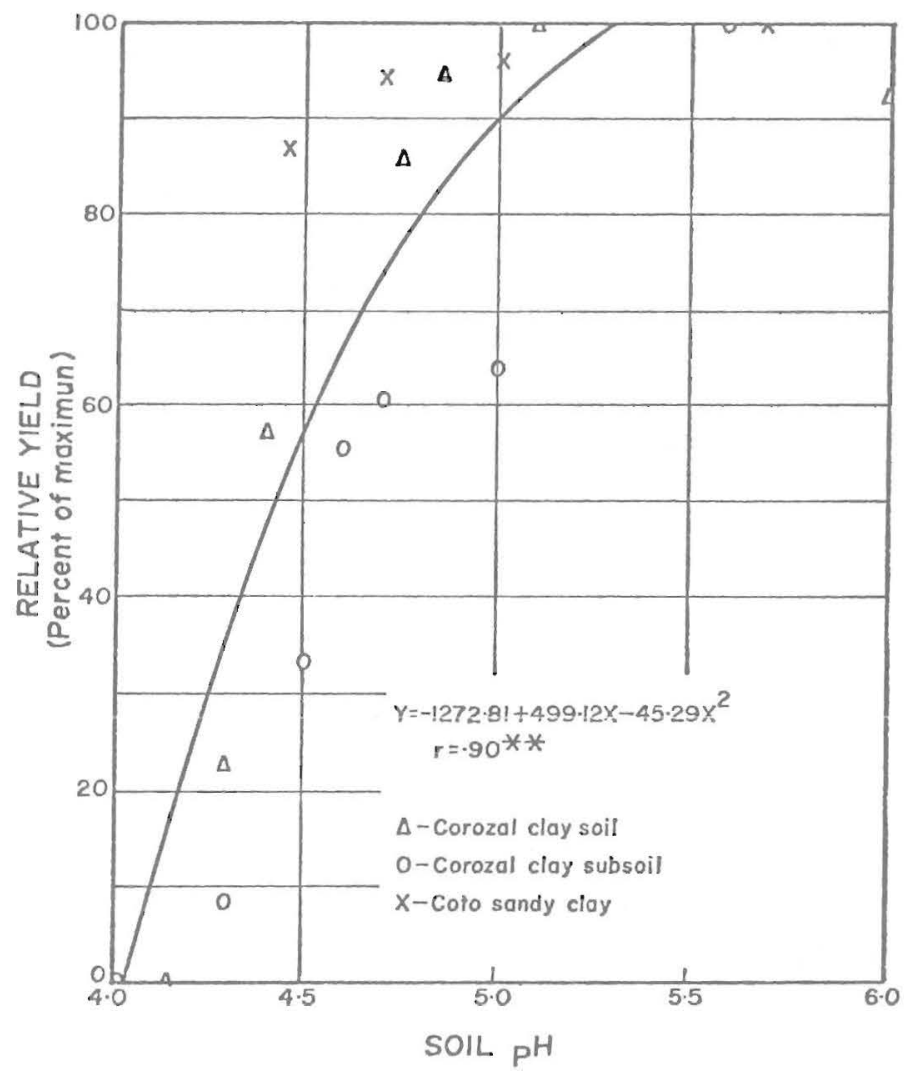

FIG. 3.-Influence of the pH of three soils on relative yields of Bonita dry beans in Puerto Rico.

Yields were highly correlated with all three soil acidity factors (table 2). Calcium, $\mathrm{Mn}$ and $\mathrm{Ca} / \mathrm{Mn}$ content of the leaves also correlated well with all soil acidity factors. The $\mathrm{Ca} / \mathrm{Mn}$ ratio has been highly correlated with snap bean yields on these soils (1).

\section{COTO SANDY CLAY}

Lower yields were obtained on the Coto than on the Corozal soil and the response to soil acidity factors was relatively small (table 1). With 
about $30 \% \mathrm{Al}$ saturation and $\mathrm{pH} 4.5$, the highest acidity occurring in the Coto soil (3), beans produced $87 \%$ and $86 \%$ of maximum yields on the Coto and Corozal soils, respectively.

Yields and foliar compositions correlated only weakly with the soil acidity factors (table 2).

\section{ALL SOILS COMBINED}

Regression analysis of the combined data for all soils (fig. 1, 2, 3) show that yields were closely correlated with all soil acidity factors.

Highest yields were obtained when essentially no exchangeable Al was present in the soil; yields decreased to around $50 \%$ of maximum at about $50 \% \mathrm{Al}$ saturation of the soil and to 0 at near $80 \% \mathrm{Al}$ saturation (fig. 1).

Yields decreased with increasing exchangeable Al/exchangeable bases

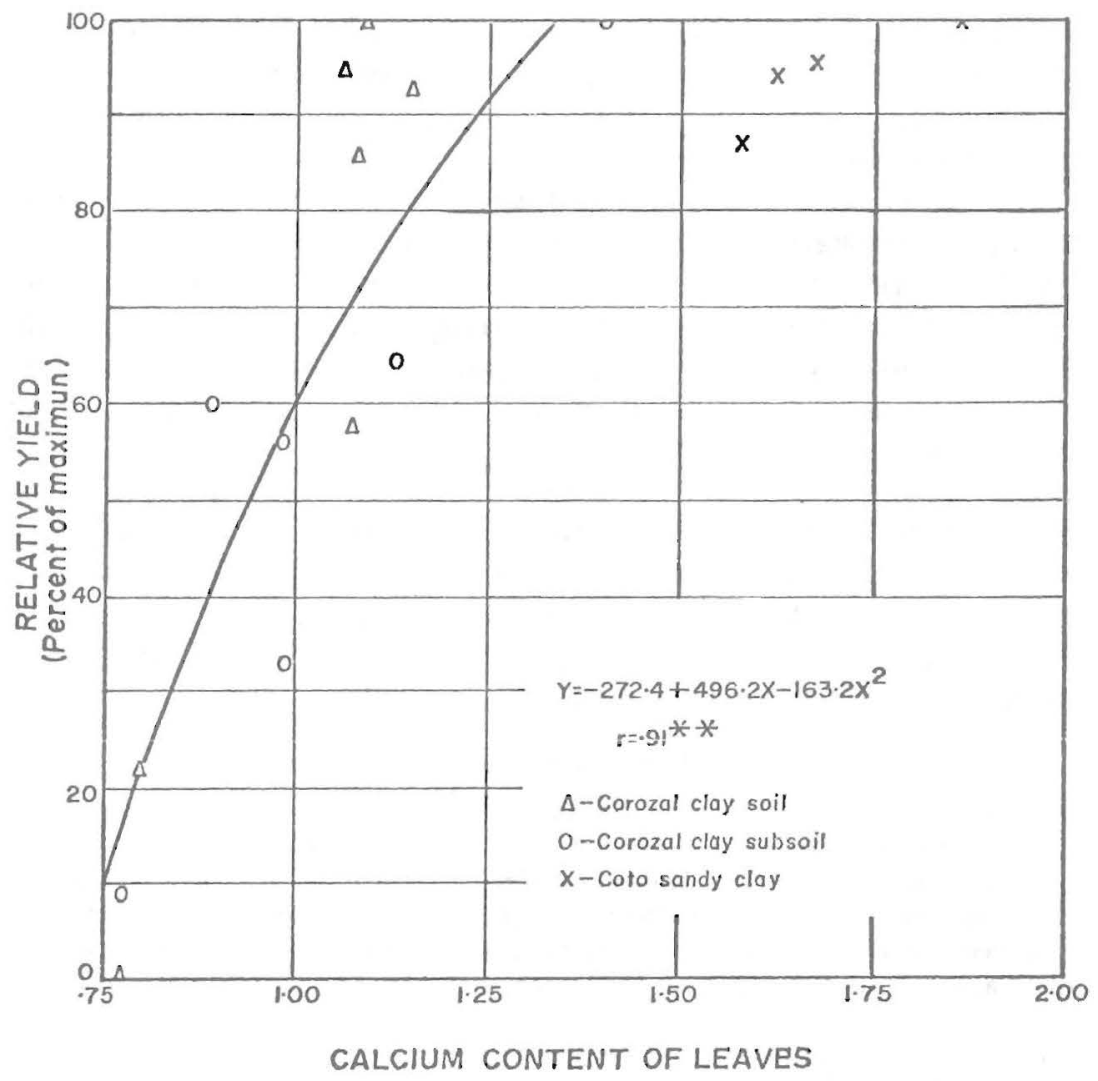

FIG. 4.-Relationship between calcium content of bean leaves and relative yield of Bonita dry beans. 
(fig. 2). Yields increased with increasing $\mathrm{pH}$ from 0 at $\mathrm{pH} 4.0$ up to $100 \%$ at around $\mathrm{pH} 5.2$ (fig. 3).

Yields increased with increasing Ca content of the leaves (fig. 4) with maximum yields obtained when Ca content of the leaves was about $1.3 \%$.

\section{RESUMEN}

Se estudió el efecto de los factores de acidez del suelo en los rendimientos y composición foliar de habichuelas blancas de la variedad Bonita en dos Ultisol en Corozal y un Oxisol en Isabela.

En el suelo Corozal (Ultisol) la producción de habichuelas no se redujo hasta que el pH bajó a 4.7, que correspondió a 30\% de saturación de la capacidad de cambio del suelo con aluminio. Al aumentar la acidez sobre este nivel, se redujo señaladamente la producción de habichuelas hasta el punto en que no se produjo cosecha alguna cuando el pH del suelo bajó a 4.1 , equivalente a un $80 \%$ de saturación de la capacidad de cambio con aluminio. El contenido de calcio en las hojas se redujo cuando el pH del suelo bajó de 4.4, pero el contenido de los otros nutrimentos no se afectó.

En el subsuelo Corozal se obtuvieron resultados similares aunque los efectos de los aumentos en la acidez en la producción de las habichuelas fueron más señalados que en el suelo.

En el suelo Coto (Oxisol) las habichuelas produjeron menos que en el Corozal y respondieron menos a aumentos de la acidez del suelo.

Cuando se combinaron los resultados obtenidos en los tres experimentos, se obtuvieron correlaciones altamente significativas entre rendimiento y $\mathrm{pH}$, y rendimiento y saturación de la capacidad de cambio del suelo con aluminio. El contenido de calcio en las hojas correlacionó bien con la producción de las habichuelas.

Los rendimientos mayores de habichuelas se obtuvieron cuando los suelos tuvieron un pH de 5.2 o más, a cuyo nivel no había aluminio cambiable en el suelo. Los rendimientos se redujeron a un 50\% del máximo cuando el nivel de saturación con aluminio alcanzó un 50\% y a 0 cuando el nivel de aluminio alcanzó un $80 \%$ de saturación del complejo de cambio del suelo, a un pH de alrededor de 4.0.

\section{LITERATURE CITED}

1. Abruña-Rodriguez, F., Pearson, R. W., and Pérez-Escolar, R., 1975. Lime response of corn and beans in typical Ultisols and Oxisols of Puerto Rico. In: Soil Management in Tropical America, Univ. Consortium of Soils of the Tropics, N. C. State Univ.

2. —- Pérez-Escolar, R., Vicente-Chandler, J., Figarella, J., and Silva, S., 1974. Response of green beans to acidity factors in tropical soils, J. Agric. Univ. P.R. 58 (1): 44-58.

3. Abruña, F., Vicente-Chandler, J., Rodríguez, J., Badillo, J. and Silva, S., 1978. Crop response to soil acidity factors in Ultisols and Oxisols in Puerto Rico. V. Sweet potatoes, J. Agric. Univ. P.R. 63 (2): 250-67.

4. Awan, A. B., 1964. Effect of lime on availability of phosphorus in Zamorano soils. Soil Sci. Soc. Am. Proc. 28: 672-73. 
5. Cutcliffe, J. A. and Simpson, W. G., 1974. Effect of lime on yield of field beans, Can J. Plant. Sci. 54: 589-90.

6. Evans, C. E. and Kamprath, E. J., 1970. Lime response as related to percent Al saturation, solution Al and organic matter content, Soil Sci. Soc. Am. Proc. 34: 89396.

7. Foster, H. L., 1970. Liming continuously cultivated soils in Uganda, East Afr. Agric. For. J. 36: 58-69.

8. Gutiérrez, P. U., Infante, M. and Pirchinat, A., 1975. Situación del cultivo del frijol en América Latina, Centro Int. Agric. Trop. CATIE, Costa Rica, Serie E. S-19.

9. Heald, W. R., 1965. Calcium and magnesium: In: Methods of Soil Analysis, Am. Soc. Agron., Agron. Series 9: 999-1009.

10. Mascarenhas, H. A. A., D’Artagnan, L., Almeida, L. D., Miyasaka, S., Freire, E. S., Cione, J., Hiroce, R. and Pio Nery, J., 1969. Adubação mineral do feijoeiro. XII. Efeitos da calagem, do nitrogenio e do fósforo en solo Latosolo Vermelho Amarelo do vale do Ribeira, Bragantia 28 (7):71-83.

11. MeLean, E. O., 1965. Aluminum, In Methods of Soil Analysis, Am. Soc. Agron., Agron. Series 9: 994-96.

12. Miyasaha, S., Freire, E. S., Mascarenhas, H. A. A., and Igue, T., 1965. Adubação verde, calagem e adubação mineral do feijoeiro em solo con vegetação do cerrado, Bragantia $24(26): 321-38$.

13. Santiago, P., 1972. The role of organic matter in the inhibition of aluminum toxicity in an Ultisol, Thesis. Cornell University.

14. Spain, J. M., Francis, C. A., Howler, R. W. and Calvo, E., 1974. Differential species and varietal tolerance to soil acidity. In: Soil Management in Tropical America, University Consortium on Soils of the Tropics, N. C. State Univ. 